\title{
An early stimulation of solid feed intake slightly influences the morphological gut maturation in the rabbit
}

\author{
Mélanie GALLOIS ${ }^{\mathrm{a}}$, Thierry GIDENNE ${ }^{\mathrm{a} *}$, Laurence FORTUN-LAMOTHE ${ }^{\mathrm{a}}$, \\ Isabelle LE HUEROU-LURON ${ }^{b}$, Jean-Paul LALLÈS ${ }^{b}$ \\ a Station de Recherches Cunicoles, INRA, BP 52627, 31326 Castanet-Tolosan, France \\ b INRA, UMR SENAH, Système d'élevage, Nutrition Animale et Humaine, 35590 St Gilles, France
}

(Received 20 September 2004; accepted 6 December 2004)

\begin{abstract}
The impact of dietary factors on the gut morphological maturation is poorly documented in rabbits. The weights of the digestive segments as well as the morphology of villi and crypts along the small intestine were analysed weekly from day 14 till day 49, in two rabbit groups weaned at either 21 (W21 group, $n=12$ litters) or 35 days (W35 group, $n=12$ litters) of age. From 21 till 35 days, the W21 group ate 57\% more solid feed than the W35 group $(P<0.01)$, and presented slighter body weights from day 28 till day $49(-9 \%, P<0.05)$. Tissue weights of the empty digestive segments, as expressed relative to the body weights, were higher in the W21 than in the W35 group from day 28 till day $49(P<0.001)$, whereas absolute tissue weights appeared similar (except for the proximal colon). From day 28 to day 49 , small intestinal villi grew in height and surface area $(P<0.05)$ whereas the crypts deepened. Villous height followed a proximo-distal decreasing gradient from the duodenum to the ileum $(P<0.05)$ from day 28 onward. The villous height to width ratio changed with the beginning of significant solid feed intake: from a thin shape until day 21 , villi became wider from day 28 on. The effect of weaning age on mucosal morphology was insignificant, except for the jejunal crypts whose surface area and depth were higher in the W21 group. The present results showed that morphological changes in the digestive tract of young rabbits were weakly influenced by an early stimulation of solid feed intake.
\end{abstract}

gut maturation / rabbit / weaning / intestinal morphology / digestive mucosa

\section{INTRODUCTION}

Digestive disorders are a major cause of mortality and morbidity in the rabbit around the weaning $[1,2]$. Susceptibility to digestive troubles may be a consequence of a maladjustment of the gastrointestinal function to the transition from doe's milk to a solid diet, probably not adapted to young digestive capacities. Indeed, the digestive tract of rabbits is subject to many changes around weaning: an important anatomical development of the distal relative to the proximal parts of the digestive tract, associated with the development of microbial fermentation and caecotrophy [3]; maturation of the digestive function of the gut illustrated by decreasing (lactase) or increasing

* Corresponding author: gidenne@toulouse.inra.fr 
(amylase, trypsine) intestinal enzymatic activities with age [4]. These changes are probably driven by an ontogenic programming but other factors like diet and microbiota can impact significantly on it [5].

Understanding the potential influence of the dietary factors on the gastrointestinal function development is essential in order to determine the nutritional requirements of the young to prevent digestive diseases. Since the small intestinal mucosa represents a major site of digestion and absorption of nutrients, as well as an important area of defence against antigenic aggressions, its functional and morphological development would partly explain the evolution of the digestive capacities, as well as the organisation of the mucosal barrier function in young. In rabbits, intestinal morphological maturation is still poorly documented. Some studies report an increased villous length and width with age $[6,7]$ and a change in shape: from finger-like, villi become tongue and leaf-shaped [8]. But, to our knowledge, the potential influence of dietary factors on the development of the digestive mucosa has only been partially investigated [9].

Thus, we studied the impact of an earlier transition from milk to a solid diet on the anatomical development of the digestive tract and on the morphological maturation of the small intestinal mucosa, by modulating the weaning age (21 vs. 35 days).

\section{MATERIAL AND METHODS}

\subsection{Experimental design}

Twenty-four litters equalised to nine young rabbits at 14 days of age (INRA strain 1067 for does) were reared in cages allowing a separate solid feed distribution to the mother and to its litter [10]. The rabbits from 12 litters were weaned at 21 days of age (W21 group), whereas the other 12 litters were weaned at 35 days of age (W35 group). Environmental temperature was maintained at $19^{\circ} \mathrm{C}$. The lights were on $16 \mathrm{~h} /$ day. From
14 till 49 days of age, all the young rabbits had ad libitum access to the same experimental feed (Tab. I). All the does were fed the same commercial feed. They were moved to other cages the day of weaning, whereas young rabbits stayed at the same place till the end of the experiment (49 days). The does were inseminated 25 days after kindling to avoid interactions between gestation and milk production. At 14, 21, 28, 35, 42 and 49 days of age, the rabbits, all individually identified, were weighed before suckling and the solid feed intake was measured per litter. These same days, the litter milk consumption was measured by weighing the does before and after the suckling. The animals were handled according to the care of animals in experimentation, in agreement with French national legislation (decree 2001-486, 06/06/2001).

The following chemical analyses were carried out on feed: dry matter $\left(24 \mathrm{~h}\right.$ at $\left.103^{\circ} \mathrm{C}\right)$, ash $\left(5 \mathrm{~h}\right.$ at $\left.550{ }^{\circ} \mathrm{C}\right)$, gross energy (adiabatic calorimeter PARR, Moline, Illinois, USA), fibres (neutral detergent fibre, acid detergent fibre and acid detergent lignin) according to the sequential method of Van Soest et al. [11] with an amylolytic pre-treatment, and crude fat according to the method described by Alstin and Nilsson [12]. Starch was hydrolysed enzymatically and the resulting glucose released was measured using the hexokinase glucose-6-phosphate dehydrogenase system (D-Glucose ${ }^{\circledR}$, Boëhringer Mannheim). Nitrogen was determined according to the DUMAS combustion method using the Leco auto-analyser (model FP-428, Leco Corp., St Joseph, MI, USA) and converted to crude protein using the factor 6.25. Crude fat in milk was determined according to the method of Folch et al. [13], and dry matter by freeze-drying followed by oven-drying during $24 \mathrm{~h}$ at $103{ }^{\circ} \mathrm{C}$. Milk composition was determined on one mean sample obtained from seven does of the same rabbitry at the twenty-fifth day of lactation. Milk was collected on does separated from their litters since the day before, by using a vacuum pump connected to a milker tube. 
Table I. Experimental diet and milk composition.

\begin{tabular}{lcc}
\hline & $\begin{array}{c}\text { Experimental diet } \\
\text { (fed to young rabbit) }\end{array}$ & Doe's milk \\
\hline Ingredients, $\mathrm{g} \cdot \mathrm{kg}^{-1}$ & 130 \\
$\quad$ Sugar beet pulp & 250 \\
Alfalfa meal & 50 & \\
Soybean meal & 110 & \\
Wheat & 40 & \\
Extruded soybean seeds & 138 & \\
Sunflower meal & 200 & \\
Wheat bran & 50 & 261 \\
Sucrose & 22 & 129 \\
Minerals and vitamins ${ }^{1}$ & 10 & 88 \\
Sunflower oil & & \\
& & \\
Nutrients, $\cdot \mathrm{kg}^{-1}$ & 918 & \\
Dry matter & 177 & \\
Crude protein $(\mathrm{N} \times 6.25)$ & 36 & 25 \\
Crude fat & 98 & 1632 \\
Starch & 189 & \\
Acid detergent fibre & 143 & \\
Hemicellulose & & \\
Cellulose & 133 & \\
Ash & 78 & \\
Gross energy $\left(\mathrm{kcal}^{3} \cdot \mathrm{kg}^{-1}\right)$ & 4106 & \\
\hline
\end{tabular}

${ }^{1}$ Contained: $6 \mathrm{~g} \cdot \mathrm{kg}^{-1}$ of salt, $5 \mathrm{~g} \cdot \mathrm{kg}^{-1}$ of calcium carbonate, $1 \mathrm{~g} \cdot \mathrm{kg}^{-1}$ of DL-methionine, $5 \mathrm{~g} \cdot \mathrm{kg}^{-1}$ of vitamin premix (retinol $1.5 \times 10^{6} \mathrm{UI} \cdot \mathrm{kg}^{-1}$, cholecalciferol $2 \times 10^{5} \mathrm{UI} \cdot \mathrm{kg}^{-1}$, tocopherol $3000 \mathrm{mg} \cdot \mathrm{kg}^{-1}$, thiamin $\left.200 \mathrm{mg} \cdot \mathrm{kg}^{-1}\right), 5 \mathrm{~g} \cdot \mathrm{kg}^{-1}$ of robenidine (13 $\left.200 \mathrm{mg} \cdot \mathrm{kg}^{-1}\right)$.

${ }^{2}$ Hemicellulose $=$ neutral detergent fibre - acid detergent fibre.

${ }^{3}$ Cellulose $=$ acid detergent fibre - acid detergent lignin.

\subsection{Sacrifices, measurements and sampling}

Fourteen and 21 days after kindling, one rabbit per litter was sacrificed by cervical dislocation in 12 litters, according to the Report of the AVMA Panel on Euthanasia. Thereafter, one kit per litter was slaughtered weekly till 49 days in all litters, when the suckling occurred. They were chosen as representative of the average litter weight, not adopted and healthy. The slaughter was carried out between 10:00 and 14:30, $3 \mathrm{~h}$ after the suckling and the solid feed removal. The litter size was maintained constant until the last weaning, by replacing dead (till
21 days) or sacrificed (till 28 days) rabbits using young of the same age and similar body weight from other replacement litters conducted similarly to the experimental ones.

Full and empty fresh weights of each segment of the digestive tract were measured: stomach, small intestine, caecum and appendix, and proximal colon.

Duodenum, jejunum and ileum were considered as representing respectively the first $20 \%$, the following $60 \%$ and the remaining $20 \%$ of the total length of the small intestine. Samples of $1 \mathrm{~cm}$ in length were taken from the middle of each segment of the 
small intestine, then opened longitudinally and rinsed with saline solution $\left(\mathrm{NaCl} 9 \mathrm{~g} \cdot \mathrm{L}^{-1}\right)$. Thereafter, these samples were placed in a solution of buffered formaline during 12 to $24 \mathrm{~h}$ for fixation, and stored in ethanol $90 \%$ (v/v) until analysis.

\subsection{Histological analysis}

Intestinal samples from 5 rabbits were analysed each at 14 and 21 days, and the samples of 5 animals per weaning group were examined at 28, 35, 42 and 49 days. Small intestinal samples were investigated according to the procedure of Goodlad et al. [14]. After progressive rehydration in two baths of ethanol $(75 / 25$ then $50 / 50(\mathrm{v} / \mathrm{v}))$ and in distilled water, the samples were stained with the Feulgen reaction: first, a hydrolysis in hydrochloric acid $1 \mathrm{~N}$ at $60^{\circ} \mathrm{C}$ for $6 \mathrm{~min}$, second a soaking in Schiff reagent for $30 \mathrm{~min}$. The samples were rinsed in distilled water then stored in a $45 \%$ acetic acid solution until analysis.

Villi and crypts were carefully individualised under a dissecting microscope. Then, the preparations were mounted between slide and strip, with the addition of an aqueous agent for microscopy (Aquamount improved "gurr" $\left.{ }^{\circledR}, \mathrm{VWR}\right)$ if not immediately analysed (jejunal and ileal samples).

Twenty villi and ten crypts of Lieberkühn from each segment were measured with a magnification of 40 and 100, respectively, using an optical microscope (Nikon Eclipse E600), a camera (Sony XC77E) and image analysis software (Visilog $5.2^{\circledR}$, Noesis). The length, width and surface area of villi and crypts were measured and length to width ratio calculated. The values were averaged for each sample for data analysis.

\subsection{Statistical analysis}

When mortality occurred, the measurements of feed intake were corrected by making the assumption that a rabbit did not eat during the two days before its death. For a period, milk intake of litters was calculated as the mean of the milk intake at the beginning and at the end of the period. Nutrient intake was estimated from average milk and solid feed compositions. The data of ill and replacement rabbits were not considered in the analysis.

Data were analysed according to the General Linear Models procedure of SAS [15]. Concerning the average weight gains and body weights, we used a split-plot model, the effect of the weaning age being tested according to the residual variability between litters. The body weight of rabbits at day 14 was introduced as a covariate. Weaning age and parity of does ( 3 levels: level $=$ parity 1 , level $2=$ parity 2 to 4 and level $3=$ parity $>4$ ), were the main effects considered for feed and nutrient intake analysis.

With respect to the digestive tract development, data before 28 days old were not considered in the general analysis in which the age, weaning age and their interaction were the main effects considered (from day 28 till day 49). Then, for each age, the potential effects of weaning age were estimated. The time at slaughter ( 2 levels: before and after 12:00) was also taken into account.

The same model was used for general analysis of morphometry data: the potential effects of age, weaning age and their interactions were tested from 28 till 49 days of age. At each age, the potential effects of weaning age were estimated. Then, the age effects were determined from day 14 till day 49 , separately for each experimental group if there was a significant interaction between age and weaning age in the general analysis. The effect of the localisation along the small intestine on villous and crypt parameters was tested at each age. $P$ values $<0.05$ were considered to be significant. Tendencies were assigned at $0.05<P<0.10$.

\section{RESULTS}

\subsection{Feed intake and body growth}

From 28 till 49 days, the body weights of the W21 rabbits were 9\% lower than those of the W35 rabbits $(P<0.05$ to $P<0.001$ 


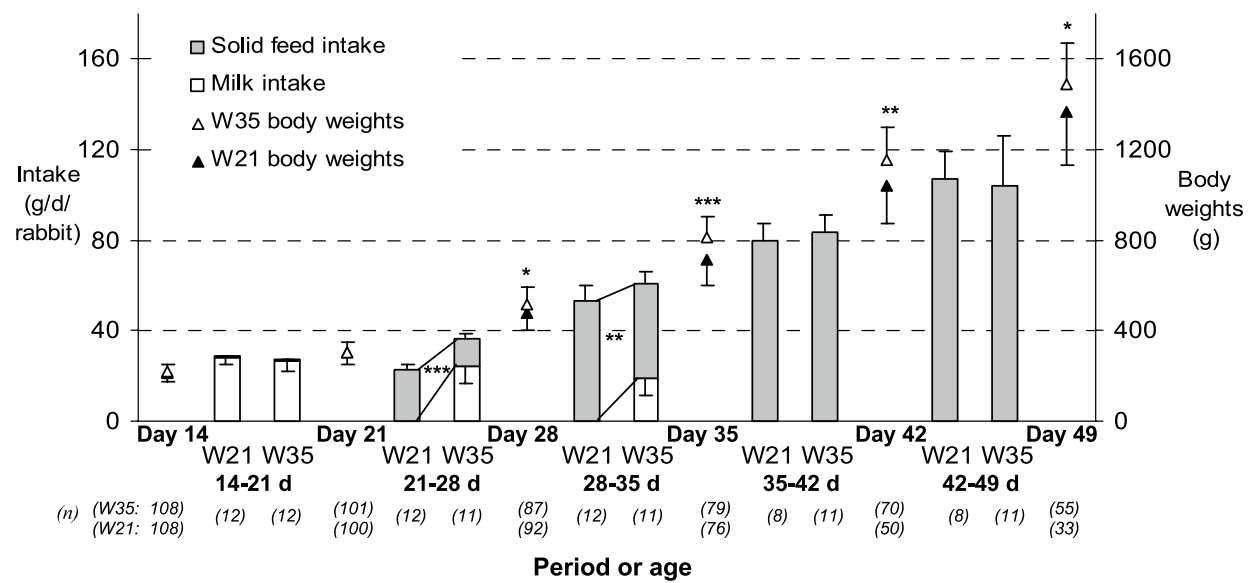

Figure 1. Body weights, solid feed and milk intake in young rabbits weaned at 21 or 35 days of age (means $\pm \mathrm{SD}, * P<0.05, * * P<0.01, * * * P<0.001$ at a given age or period).

according to age, Fig. 1). Solid feed intake was $57 \%$ higher in the W21 rabbits from 21 till 35 days $(P<0.01)$. Daily weight gain was $17 \%$ lower on average in the W21 group from day 21 to day 42 (33.8 g/day/ rabbit in the W21 group and $40.5 \mathrm{~g} / \mathrm{day} / \mathrm{rab}-$ bit in the W35 group on average from day 21 to day $42, P<0.05$ in each period), but not thereafter (W21 group: 45.1 and W35 group: $47.1 \mathrm{~g} / \mathrm{day} / \mathrm{rabbit}$ from day 42 to day 49). Total dry matter and crude energy intake (from milk and solid feed) were similar between the two groups until 35 days. Crude protein intake was higher in the W35 group, as compared to the W21 group, from day 21 till day $28(+30 \%, P<0.01)$. Crude fat intake was 3.2-fold higher from 21 till 28 days, and 1.7-fold higher from 28 till 35 days in the W35 group, as compared to the W21 group $(P<0.001$, Fig. 2$)$.

\subsection{Growth of digestive segments}

The absolute values of tissue weights of the stomach, small intestine and caecum, were not affected by weaning age, whereas the tissue weight of the proximal colon was significantly, but only slightly, higher in the W21 group from 28 till 49 days of age (Tab. II). The weight of the stomach con- tent of W35 rabbits was still higher at 28 and 35 days ( $-29 \%$ and $-35 \%$ respectively for W21 group). On day 28, the small intestine, caecum and proximal colon of W21 rabbits contained more fresh matter than those of W35 rabbits. This difference persisted until 35 days for the proximal colon.

The weights of the digestive tract tissues, relative to body weight, were higher in the W21 rabbits (Tab. III): from 28 till 49 days, $+8 \%$ for the stomach, $+11 \%$ for the small intestine, $+14 \%$ for the caecum and $+25 \%$ for the proximal colon. Concerning the weights of the contents, a similar change with time was observed, except for the stomach: $+35 \%$ for the small intestine, $+16 \%$ for the caecum and $+67 \%$ for the proximal colon from 28 till 49 days. The stomachs of the W35 group were still full of milk till 35 days for at least $87.5 \%$ of the young rabbits since slaughters occurred only $3 \mathrm{~h}$ after suckling. Accordingly, the relative weight of the stomach content was 25\% lower in the W21 group at 28 and 35 days of age.

\subsection{Development of small intestinal villi and crypts}

Intestinal villous height was not affected by weaning age (Fig. 3) but it increased 

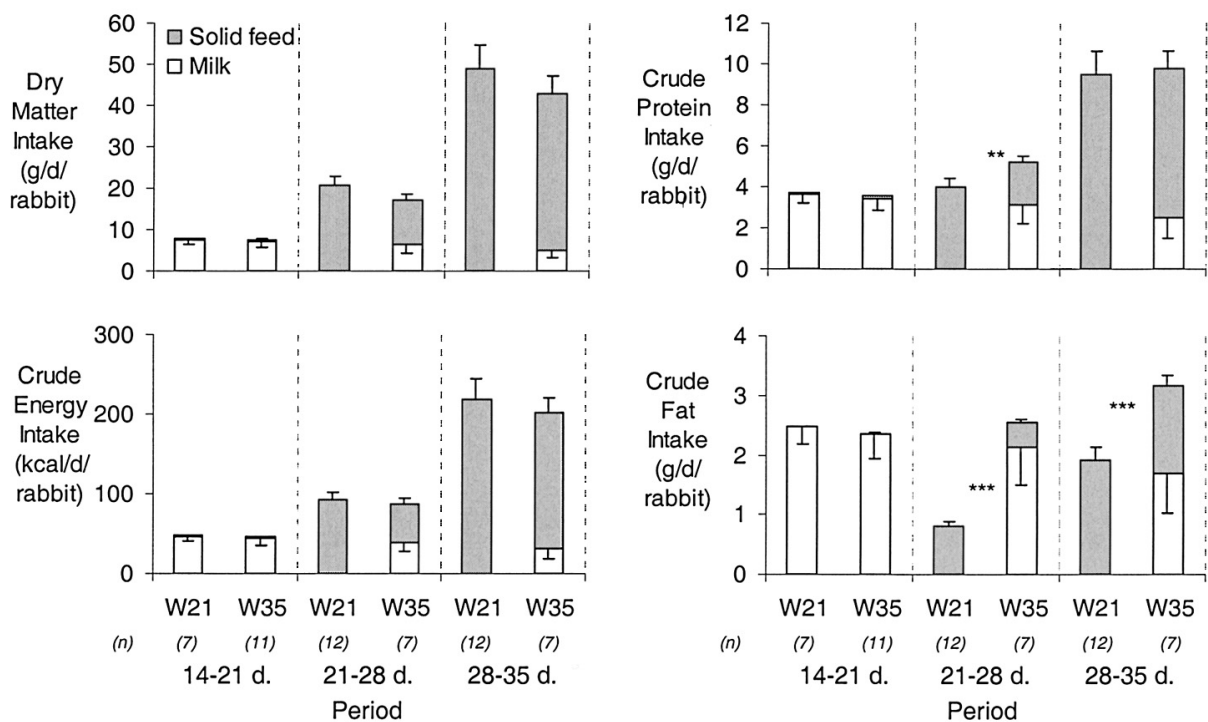

Figure 2. Feed component intake in young rabbits weaned at 21 or 35 days of age (means \pm SD, $* P<0.05, * * P<0.01, * * * P<0.001$ at a given period).

Table II. Anatomical development of the digestive tract in young rabbits weaned at 21 or 35 days of age.

\begin{tabular}{|c|c|c|c|c|c|c|c|c|c|c|c|c|}
\hline & & & \multicolumn{6}{|c|}{ Age (days) } & \multicolumn{4}{|c|}{$P$ values 1} \\
\hline & & & 14 & 21 & 28 & 35 & 42 & 49 & $\begin{array}{c}\mathrm{CVr} \\
\%\end{array}$ & $\begin{array}{c}\text { Weaning } \\
\text { age }\end{array}$ & Age & $\begin{array}{l}\text { Inter } \\
\text { action }\end{array}$ \\
\hline \multirow{4}{*}{$\mathrm{S}$} & FW & W21 & \multirow{2}{*}{3.5} & \multirow{2}{*}{5.0} & 8.5 & 11.5 & 14.3 & 16.2 & \multirow{2}{*}{8.3} & \multirow{2}{*}{ NS } & \multirow{2}{*}{$<0.001$} & \multirow{2}{*}{ NS } \\
\hline & EW & W35 & & & 8.5 & 11.7 & 14.7 & 17.1 & & & & \\
\hline & \multirow{2}{*}{ CW } & W21 & \multirow{2}{*}{25.2} & \multirow{2}{*}{31.0} & $33.6^{\mathrm{a}}$ & $37.8^{\mathrm{a}}$ & 52.3 & 60.6 & \multirow{2}{*}{22.0} & \multirow{2}{*}{$<0.001$} & \multirow{2}{*}{$<0.001$} & \multirow{2}{*}{$<0.05$} \\
\hline & & W35 & & & $47.5^{\mathrm{b}}$ & $58.0^{\mathrm{b}}$ & 53.8 & 63.2 & & & & \\
\hline \multirow{4}{*}{ SI } & EW & W21 & \multirow{2}{*}{7.8} & \multirow{2}{*}{10.7} & 19.4 & 26.9 & 38.2 & 46.9 & \multirow{2}{*}{11.7} & \multirow{2}{*}{ NS } & \multirow{2}{*}{$<0.001$} & \multirow{2}{*}{ NS } \\
\hline & & W35 & & & 19.1 & 26.1 & 36.8 & 51.1 & & & & \\
\hline & \multirow{2}{*}{ CW } & W21 & \multirow{2}{*}{0.3} & \multirow{2}{*}{0.9} & $8.7^{\mathrm{a}}$ & 10.4 & 12.7 & 18.5 & \multirow{2}{*}{46.6} & \multirow{2}{*}{0.08} & \multirow[b]{2}{*}{$<0.001$} & \multirow{2}{*}{ NS } \\
\hline & & W35 & & & $5.7^{\mathrm{b}}$ & 10.3 & 12.4 & 14.4 & & & & \\
\hline \multirow{4}{*}{$\mathrm{C}$} & EW & W21 & \multirow{2}{*}{1.4} & \multirow{2}{*}{3.6} & 8.3 & 14.2 & 18.4 & 22.6 & \multirow{2}{*}{11.3} & NS & $<0.001$ & NS \\
\hline & & W35 & & & 7.5 & 13.2 & 18.8 & 24.2 & & S & & \\
\hline & $C W$ & W21 & 10 & 59 & $26.6^{\mathrm{a}}$ & 44.6 & 61.1 & 80.1 & 224 & NS & $<0001$ & NS \\
\hline & CW & W35 & 1.0 & 5.9 & $20.6^{\mathrm{b}}$ & 45.6 & 66.0 & 80.9 & 22.4 & NS & $<0.001$ & NS \\
\hline & EW & W21 & 0.8 & 1.5 & $4.5^{\mathrm{a}}$ & 6.7 & $10.1^{\mathrm{a}}$ & 11.3 & 115 & $<0,01$ & $<0001$ & $<005$ \\
\hline $\mathrm{PC}$ & & W35 & & & $3.5^{\mathrm{b}}$ & 6.2 & $8.9^{b}$ & 11.7 & 11.5 & $<0.01$ & $<0.001$ & $<0.05$ \\
\hline PC & CW & W21 & 02 & 03 & $5.5^{\mathrm{a}}$ & $8.2^{\mathrm{a}}$ & 13.0 & 16.3 & 356 & $<005$ & $<0001$ & NS \\
\hline & Cw & W35 & 0.2 & 0.3 & $2.5^{\mathrm{b}}$ & $4.9^{\mathrm{b}}$ & 13.1 & 14.8 & 35.0 & $<0.00$ & $<0.001$ & NS \\
\hline
\end{tabular}

Data are arithmetic means; S: stomach, SI: small intestine, C: caecum, PC: proximal colon; EW: empty weight of the digestive segment in $\mathrm{g}$; CW: weight of the content of the digestive segment in $\mathrm{g}$; W21: weaning at 21 days; W35: weaning at 35 days; NS: $P$ value superior to 0.10 .

${ }^{1}$ Test realised for the 28 to 49 days period. Means in the same column for a given variable with no common superscript letters differ significantly $(P$ values $<0.05)$; $C V$ r: residual coefficient of variation; $n=7$ to 12 per group. 
Table III. Anatomical development, relative to the body weight, of the digestive tract in young rabbits weaned at 21 or 35 days of age.

\begin{tabular}{|c|c|c|c|c|c|c|c|c|c|c|c|c|}
\hline & \multicolumn{6}{|c|}{ Age (days) } & \multicolumn{4}{|c|}{$P$ values 1} \\
\hline & & & 14 & 21 & 28 & 35 & 42 & 49 & $\begin{array}{c}\mathrm{CVr} \\
\%\end{array}$ & $\begin{array}{c}\text { Weaning } \\
\text { age }\end{array}$ & Age & $\begin{array}{c}\text { Inter } \\
\text { action }\end{array}$ \\
\hline \multirow{2}{*}{\multicolumn{2}{|c|}{$\begin{array}{l}\text { BW of } \\
\text { sacrificed } \\
\text { rabbits (g) }\end{array}$}} & W21 & \multirow[b]{2}{*}{211.8} & \multirow[b]{2}{*}{302.4} & 486.8 & $711.4^{\mathrm{a}}$ & 1056.1 & $1286.9^{\mathrm{a}}$ & \multirow[b]{2}{*}{9.1} & \multirow[b]{2}{*}{$<0.001$} & \multirow[b]{2}{*}{$<0.001$} & \multirow[b]{2}{*}{$<0.05$} \\
\hline & & W35 & & & 511.0 & $827.9^{\mathrm{b}}$ & 1143.5 & $1495.2^{\mathrm{b}}$ & & & & \\
\hline \multirow{4}{*}{ S } & EW & W21 & \multirow{2}{*}{1.7} & \multirow{2}{*}{1.7} & 1.7 & $1.6^{\mathrm{a}}$ & 1.4 & $1.3^{\mathrm{a}}$ & \multirow{2}{*}{7.8} & \multirow{2}{*}{$<0.001$} & \multirow{2}{*}{$<0.001$} & \multirow{2}{*}{ NS } \\
\hline & & W35 & & & 1.7 & $1.4^{\mathrm{b}}$ & 1.3 & $1.1^{\mathrm{b}}$ & & & & \\
\hline & \multirow[t]{2}{*}{$\mathrm{CW}$} & W21 & \multirow{2}{*}{11.9} & \multirow[t]{2}{*}{10.2} & $6.9^{\mathrm{a}}$ & 5.3 & 5.0 & 4.7 & \multirow[t]{2}{*}{18.7} & \multirow[t]{2}{*}{$<0.01$} & \multirow[t]{2}{*}{$<0.001$} & \multirow[t]{2}{*}{$<0.001$} \\
\hline & & W35 & & & $9.3^{\mathrm{b}}$ & 7.0 & 4.8 & 4.2 & & & & \\
\hline \multirow{4}{*}{ SI } & EW & W21 & \multirow{2}{*}{3.7} & \multirow{2}{*}{3.6} & 4.0 & $3.8^{\mathrm{a}}$ & 3.6 & $3.7^{\mathrm{a}}$ & \multirow{2}{*}{10.1} & \multirow{2}{*}{$<0.001$} & \multirow{2}{*}{$<0.01$} & \multirow{2}{*}{ NS } \\
\hline & & W35 & & & 3.7 & $3.2^{\mathrm{b}}$ & 3.2 & $3.4^{\mathrm{b}}$ & & & & \\
\hline & \multirow{2}{*}{$\mathrm{CW}$} & W21 & \multirow{2}{*}{0.1} & & $1.8^{\mathrm{a}}$ & 1.5 & 1.2 & $1.4^{\mathrm{a}}$ & & $<001$ & NS & NS \\
\hline & & W35 & & 0.3 & $1.1^{\mathrm{b}}$ & 1.2 & 1.1 & $1.0^{\mathrm{b}}$ & 39.5 & $<0.01$ & $\mathrm{NS}$ & $\mathrm{NS}$ \\
\hline & EW & W21 & 0.7 & 1.2 & $1.7^{\mathrm{a}}$ & $2.0^{\mathrm{a}}$ & 1.8 & 1.8 & 10.9 & $<0.001$ & $<0.05$ & 0.08 \\
\hline $\mathrm{C}$ & & W35 & & & $1.5^{\mathrm{b}}$ & $1.6^{\mathrm{b}}$ & 1.6 & 1.6 & & $<0.001$ & & \\
\hline & $\mathrm{CW}$ & W21 & 05 & 2 & $5.5^{\mathrm{a}}$ & 6.3 & 5.9 & 6.2 & 210 & $<0.01$ & $<0.05$ & NS \\
\hline & $\mathrm{cov}$ & W35 & 0.5 & 2 & $4.1^{\mathrm{b}}$ & 5.5 & 5.8 & 5.4 & 21.9 & $<0.01$ & $<0.05$ & NOS \\
\hline & EW & W21 & 0.4 & 0.5 & $0.9^{\mathrm{a}}$ & $0.9^{\mathrm{a}}$ & $1.0^{\mathrm{a}}$ & 0.9 & 117 & $<0.001$ & NS & NS \\
\hline PC & & W35 & & & $0.7^{b}$ & $0.7^{b}$ & $0.8^{\mathrm{b}}$ & 0.8 & & & & \\
\hline & CW & W21 & 0.1 & 0.1 & $1.2^{\mathrm{a}}$ & $1.2^{\mathrm{a}}$ & 1.3 & 1.3 & 35.2 & $<0.001$ & $<0.01$ & 0.07 \\
\hline & & W35 & & & $0.5^{\circ}$ & $0.6^{\circ}$ & 1.1 & 1.0 & & & & \\
\hline
\end{tabular}

Data are arithmetic means; BW: body weight; S: stomach, SI: small intestine, C: caecum, PC: proximal colon; EW: empty weight of the digestive segment in $\mathrm{g} \cdot 100 \mathrm{~g}^{-1}$ of rabbit body weight; $\mathrm{CW}$ : weight of content of the digestive segment in $\mathrm{g} \cdot 100 \mathrm{~g}^{-1}$ of body weight; W21: weaning at 21 days; W35: weaning at 35 days; NS: $P$ value superior to 0.10 .

${ }^{1}$ Test realised for the 28 to 49 days period; Means in the same column for a given variable with no common superscript letters differ significantly $(P$ values $<0.05)$; CVr: residual coefficient of variation; $n=7$ to 12 per group.

between day 28 and day $49(P<0.001)$ irrespective of the weaning age (means $( \pm$ S.D. $)$ ): $746( \pm 114)$ vs. $940( \pm 119) \mu \mathrm{m}$ for the duodenum, $544( \pm 90)$ vs. $766( \pm 70) \mu \mathrm{m}$ for the jejunum and $357( \pm 30)$ vs. $570( \pm 57) \mu \mathrm{m}$ for the ileum. For the duodenum and jejunum, the villi lengthened between 14 and 21 days and then became shorter (not significant for the duodenum) before lengthening again. Ileal villi shortened from day 14 till day 28 while they lengthened from day 28 till day 49 . Whereas jejunal and ileal villi maintained their lengthening between day 42 and day 49 , duodenal villi growth seemed to be ended at day 42 .
Weaning age did not impact significantly on crypt depth, except for the jejunal crypts, which were deeper in the W21 group $(+10 \%$ on average from 28 to 49 days of age, $P<$ 0.05). Crypts deepened with age, irrespective of the weaning age (Fig. 3). Crypt deepening in the ileum seemed more progressive for the W35 rabbits compared with W21 rabbits (age $\times$ weaning age interaction, $P=$ $0.05)$.

The villous height to width ratio informs on the villous shape (Fig. 3). From day 28 till day 49 , whatever the segment of the digestive tract considered, neither age nor weaning age had a significant effect on this ratio. 
$\underline{\text { Duodenum }}$

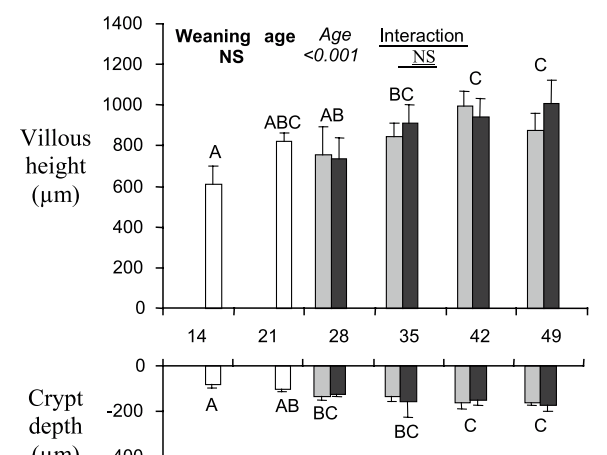

$(\mu \mathrm{m})$

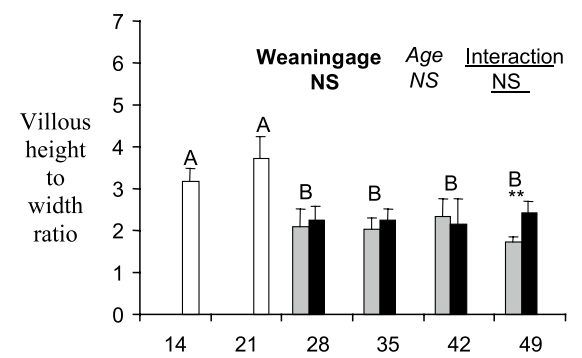

Jejunum

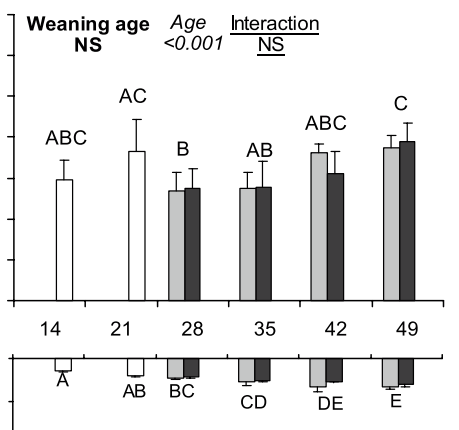

$\underset{<0.05}{\underset{0.00}{\text { Weaning age }}} \underset{<0.001}{\text { Age }} \frac{\text { Interaction }}{\mathrm{NS}}$

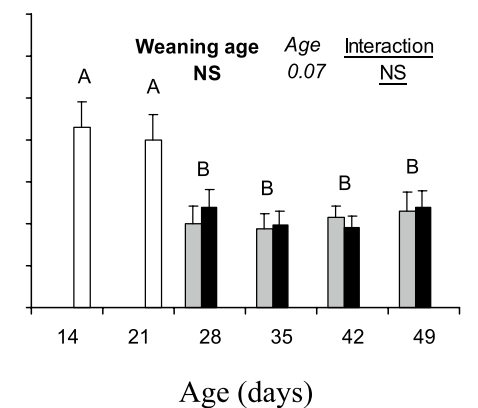

$\underline{\text { Ileum }}$

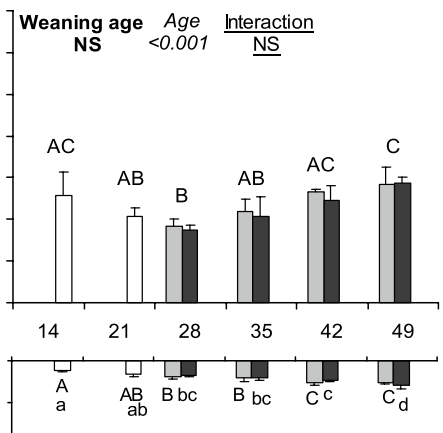

$\underset{\text { Weaning age }}{\text { NS }} \underset{<0.001}{\stackrel{\text { Interaction }}{0.05}}$

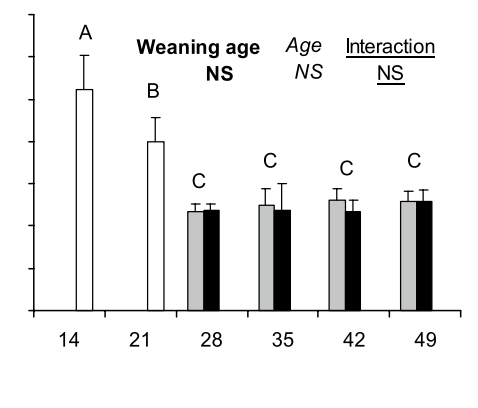

Figure 3. Villous height, crypt depth and villous height to width ratio along the small intestine in rabbits weaned at 21 or 35 days of age ( $\square$ Before weaning, $\square$ Weaning at $21 \mathrm{~d}$, Weaning at $35 \mathrm{~d}$, means \pm SD). From 28 till $49 \mathrm{~d}$, the model included the effects of weaning age, age and interaction $(P$ values, NS: $P>0.10)$; Age effects were separately analysed from 14 to 49 d: means with no common superscript letters differed significantly $(P<$ 0.05 ), with capital letters for weaning at $21 \mathrm{~d}$, and with small letters for weaning at $35 \mathrm{~d}$ if significant interaction with weaning age. Within each age, the effect of weaning age was tested $(* P<0.05, * * P<0.01$, ** $P<0.001)$. 
Villi were nearly twice as long as wide (2.2, 2.1 and 2.5 times respectively for the duodenum, jejunum and ileum). Nevertheless, on day 49, the duodenal villi of W35 rabbits appeared proportionally longer $(P<0.01)$ than those of the W21 rabbits. Changes in shape could be noticed: the villi were thin till 21 days, becoming wider from day 28 whatever the digestive segment.

Villous surface area increased with age without any difference between the 2 groups, except on day 42 for the jejunum and on day 35 for the ileum where the villous surface area of W21 rabbits was greater $(+26 \%$ and $+18 \%$, respectively, Fig. 4). The surface area of duodenal crypts was similar between the two weaning groups. For the jejunum, the crypt surface area of the W21 group was higher by considering the whole period from day 28 till day $49(+19 \%$ on average). Ileal crypts of the W21 group seemed to have reached their maximal area on day 42 (significant age $\times$ weaning age interaction, $P<0.05)$. Crypt surface area increased with age whatever the digestive segment.

A proximo-distal decreasing gradient in the small intestinal mucosa was highlighted irrespective of the weaning age. For most ages, the parameters of morphometry were significantly higher in the duodenum, lower in the ileum and intermediate but different in the jejunum, e.g. on day 28 (means $( \pm$ S.D.): $21.9( \pm 4.7), 9.8( \pm 1.6)$ and $3.9( \pm 0.7)$ for villous surface area $\left(\times 10^{4} \mu \mathrm{m}^{2}, P<0.001\right)$, $746.4( \pm$ 114.0), $543.6( \pm 89.7)$ and 357.1 $( \pm 29.6) \mu \mathrm{m}$ for villous height $(P<0.001)$, and $129.0( \pm 14.1), 88.0( \pm 7.7)$ and $75.2( \pm$ $7.0)$ for crypt depth $(P<0.001)$, respectively for the duodenum, jejunum and ileum. No differences between sites were observed on day 14 for villous height and on day 21 , the ileal villi were shorter compared to the other digestive segments. Duodenal values were significantly higher than jejunal and ileal values, without differences between these two last sites, for the villous surface area on day 14 and for crypt depth on days 14,35 , and 49 . Crypts tended to be deeper in jejunal than in ileal segments on
21 and 42 days (respectively $P=0.093$ and $P=0.089$ ).

\section{DISCUSSION}

\subsection{Feed intake and body growth}

The lighter body weights of early-weaned rabbits, compared to traditionally weaned rabbits (at day 35), suggested that their increased dry feed intake was insufficient to compensate for the withdrawal of milk at 21 days, and then to cover their dietary requirements. Scapinello et al. [16] also reported that a lower milk intake in litters of $10 \mathrm{vs} .4$ pups stimulated solid feed intake before weaning, but led to lighter rabbits until day 42. Similarly, Xicatto et al. [17] showed that body weights at 32 days were positively correlated with the weaning age (weaning at 21, 25 or 28 days of age), but became similar at 56 days.

Despite the change in milk composition according to the stage of lactation [18-20] that we did not consider in our calculations, nutrient intake differed in quantity and quality, according to weaning age. Classical-weaned rabbits ate more crude protein and fat than early-weaned rabbits, whereas crude energy intakes were similar. However it is assumed that milk is almost fully digested on the contrary to solid feed. Thus, digestible energy intake would probably be lower for early-weaned rabbits, which would partly explain the differences in weight gains. Moreover, various non-nutrient components present in milk, like growth factors and immunoglobulins, are likely to influence growth. Some studies have reported that compensatory growth often occurs with late fattening, leading to similar body weights at slaughter [17, 21, 22].

\subsection{Growth of digestive segments}

The weights of the stomach and small intestine decreased between 28 and 49 days 
Duodenum

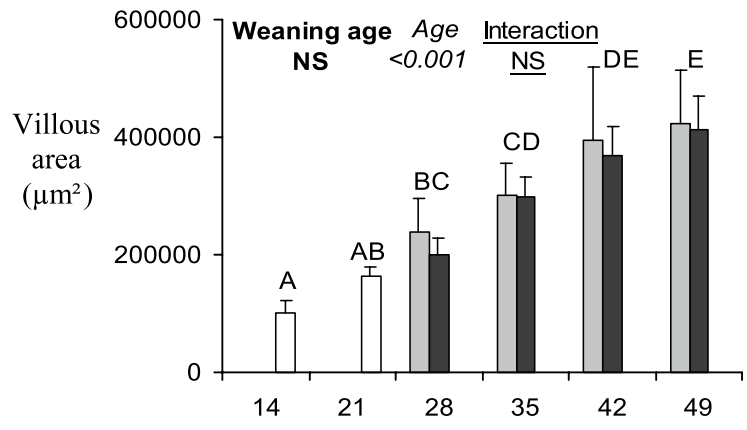

Crypt

area

$\left(\mu \mathrm{m}^{2}\right)$

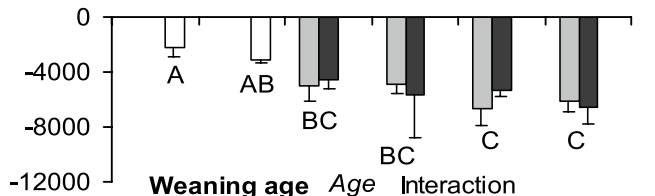

-12000 Weaning age $\underset{\text { NS }}{A g e} \frac{\text { Interaction }}{\text { AS }}$

\section{Jejunum}

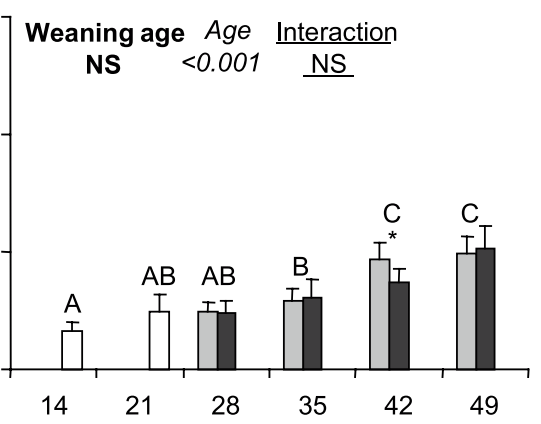

$\mathrm{A}$

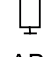

$\mathrm{AB} \quad \mathrm{AB}$

Weaning age $\underset{<0.01}{A g e} \frac{\text { Interaction }}{\text { NS }}$

Age (days) $\underline{\text { Ileum }}$
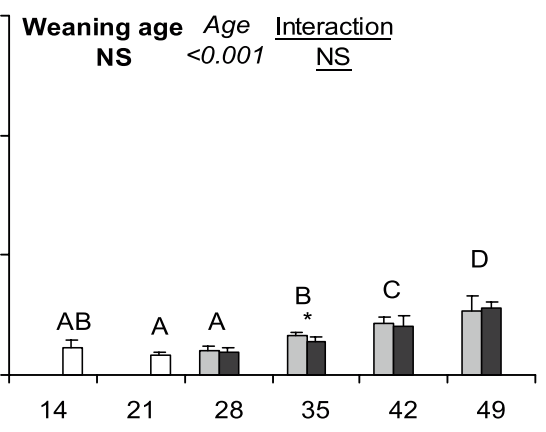

$\mathrm{AB} \mathrm{BC}^{\mathrm{ab}}$
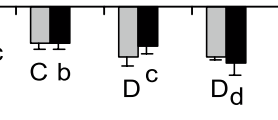

Weaning age $\underset{N S}{\text { Age }} \underset{<0.001}{\text { Interaction }}$

Figure 4. Villous and crypt area along the small intestine in young rabbits weaned at 21 or 35 days of age ( $\square$ Before weaning, $\square$ Weaning at $21 \mathrm{~d}$ Weaning at $35 \mathrm{~d}$, means \pm standard deviations). From 28 till $49 \mathrm{~d}$, the model included the effects of weaning age, age and interaction ( $P$ values, NS: $P>0.10)$; Age effects were separately analysed from 14 to $49 \mathrm{~d}$ : means with no common superscript letters differed significantly $(P<0.05)$, with capital letters for weaning at $21 \mathrm{~d}$, and with small letters for weaning at $35 \mathrm{~d}$ if significant interaction with weaning age. Within each age, the effect of weaning age was tested $(* P<0.05$, ** $P<0.01$, *** $P<0.001)$. 
when expressed relative to the body weights, while those of the large intestine remained similar or increased during this period, which shows the increasing importance of the large intestine, as previously described [3]. At least until day 49, the development of the digestive tract, relative to body weight, was more important in early-weaned rabbits. Xicatto et al. [23] showed that the earlier the rabbits were weaned, the more important were the empty and full relative weights of most of the digestive segments. This phenomenon may have resulted from a higher intake of the dry feed, which could lead to a more important mechanical stimulation, thus to a thickening and an elongation of the digestive wall.

However, according to Laplace and Lebas [24], the body weight of rabbits among a population of a given age is not a good discriminating factor for the growth of digestive segments. When considering the absolute weights of the digestive segments, it appeared that only the proximal colon was more developed in early-weaned rabbits. Thus, the higher values relative to body weights in early-weaned rabbits should only be explained by their lower body weights.

\subsection{Development of small intestinal villi and crypts}

Few literature deals with the impact of weaning and age on intestinal mucosa morphology in rabbits. On the contrary to the present results, Guttierez et al. [9] observed shorter jejunal villi and deeper crypts on day 35 in rabbits weaned at 25 days compared with suckling rabbits. In other animal species, weaning seems more stressful for the small intestinal mucosa as compared to rabbits. In piglets, a shortening of villous height is classically observed in the few days following the weaning $[25,26]$. Different hypotheses have been suggested to explain this phenomenon. A stress provoked by weaning could lead to villous atrophy. On the contrary to the rabbit, for which the transition from milk to solid feed is progres- sive from 18 days when they begin to eat a dry diet, the weaning is more brutal in pigs concerning the dietary changes. However, relationships with corticoids or epinephrine secretions have never been shown to reinforce this theory [27]. Some milk factors like epidermal growth factor, insulin and insulin-like growth factor [28] or polyamines [29], could have a positive action on villous growth [30]. However, in our study, milk intake was not essential for villous growth: villi of suckling and early-weaned rabbits evolved similarly with age. In piglets, villous shortening is mainly explained by the transient anorexia provoked by weaning [31], and consequently an insufficient digestible energy intake is the major factor accounting for both the shortening of villi and the speed of recovery [26]. The decrease in height observed on day 28 for the jejunum appeared after the beginning of significant solid feed intake in the two weaning groups, irrespective of the weaning age. Thus, the shortening or the absence of elongation of villi could be due more to the beginning of solid feed intake than to its level in rabbits. However, a more frequent sampling between 21 and 28 days could have allowed to highlight a possible differential evolution of the villous height among the two weaning ages. Indeed, the villi of weaned rabbits may have undergone an important decrease followed by an increase, whereas the villi of suckling rabbits may have progressively decreased, leading to similar heights at 28 days. In all cases, an abrasion of villi by solid feed may be suspected: mechanical action, transient hypersensitivity to some components, presence of some anti-nutritional factors [25]. However, $\mathrm{Yu}$ and Chiou [7] have reported that, between 14 and 28 days of age, the villi of each segment of the small intestine grow in height.

In our study, divergent changes in villous surface area (an increase) and height (a decrease then an increase) suggested that this last parameter was insufficient to estimate the absorptive capacity of the mucosa. As reported by Wiese et al. [32], villous 
height is not representative of the absorptive surface, because of the different villi shapes (a short and wide villus may have a greater surface area than a long and thin villous). The present results showed a higher enlargement than the lengthening of villi from day 28 onward. This change in shape might increase the resistance of the intestinal mucosa towards solid feed, more abrasive than milk. In our study, the absorption surface did not seem to be influenced by the solid feed intake level, but only by age. Before day 28 , for every digestive segment, the villi were thinner and finger-shaped. Thereafter, they became leaf and tongue-shaped as shown in previous studies [7, 8]. In parallel, the villous surface area increased with age. Absolute values of these criteria must be considered with caution: the surface represented by microvilli, thickness of villi and density of villi on mucosa have not been taken into account. Keelan et al. [6] reported that between 6-weeks-old and adult rabbits, villi shortened, but thickened, which led to a similar villous surface. Nevertheless, we assumed that this increase in surface area corresponded to a higher absorptive potential, thus to a greater digestive capacity of rabbits. Concerning the crypts, Goodlad et al. [14] previously described that their surface was correlated with the number of mitoses. Assuming such an assertion, cellular renewal seems more important in the jejunum of early-weaned rabbits than in classical-weaned-rabbits, without any incidence in villous morphometry. The loss of enterocytes could be more important at the apex of villi (solicitation for digestion and absorption, elimination of micro-organisms, feed abrasion). Thus, crypts would provide a greater cell renewal to compensate for this loss. With age, the increase in the villus surface area would partly result from an increased crypt cell production, thus may be linked to the increase in crypt surface area. Indeed, according to Keelan et al. [6], the cell size does not change with age, thus the increase in villous surface area would be the result of an increase in the number of enterocytes. The number of crypts per villus, not evaluated in our study, may also change with time and be partly responsible for the villous surface area increase.

Along the small intestine, we measured a decrease in villous surface area and height, and in crypt depth with an increasing distance from the stomach. Conflicting data are reported in rabbits [7,33], and in piglets [31, 32, 34-37]. Samplings along the small intestine, the analyses procedures and calculations were not homogenous among the studies, which could partly explain these discrepancies. However a recent study [38] showed the same gradient in villous length in adult rabbits, but with weaker differences between segments: around or less than $100 \mu \mathrm{m}$ between two consecutive segments. In our study, villous lengthening was stopped on day 42 for the duodenum but not for the two other digestive segments, suggesting that differences between segments would probably be weaker after 7 weeks of age. This observation would be in agreement with previous studies having demonstrating a proximo-distal gradient of maturation along the small intestine $[8,39]$. In piglets, a spatial and temporal effect of weaning on villous atrophy and recovery has been described. Villous atrophy immediately post-weaning is more pronounced in the proximal than in distal parts of the small intestine [26].

In conclusion, the solid feed intake pattern was strongly affected by weaning age. A sharp increase in solid feed intake induces a higher development of the different digestive segments relative to the body weights of rabbits, resulting either from a real increase in digestive development or from the lower body weights of early-weaned rabbits. The development of the small intestine mucosa was moderately affected by the earlier transition from milk to exclusive solid feed intake, suggesting that early mucosa maturation would be quite independent of diet origin (milk vs. pelleted diet). 


\section{ACKNOWLEDGEMENTS}

The authors thank the technical staff of the Station de Recherches Cunicoles (INRA Toulouse), and of the UMR SENAH (INRA Rennes) for their collaboration. The authors also thank $\mathrm{H}$. Rémignon (Laboratory of Zootechnie et Qualité des Produits Animaux, ENSA Toulouse, France) for his help in image analysis of intestinal samples. This study was partly supported by Cybelia (Glon group, Paris, France).

\section{REFERENCES}

[1] Guerder F. RENALAP : de bons résultats. Cuniculture 2002, 29: 150-152.

[2] Marlier D, Dewrée R, Delleur V, Licois D, Lassence C, Poulipoulis A, Vindevogel H. Description des principales étiologies des maladies digestives chez le lapin européen (Oryctolagus cuniculus). Ann Méd Vét 2003, 147: 385-392.

[3] Lebas F, Laplace JP. Mensurations viscérales chez le lapin. I. Croissance du foie, des reins et des divers segments intestinaux entre 3 et 11 semaines d'âge. Ann Zootech 1972, 21: 37-47.

[4] Dojana N, Costache M, Dinischiotu A. The activity of some enzymes in domestic rabbits before and after weaning. Anim Sci 1998, 66: 501-507.

[5] Kelly D, Coutts AGP. Development of digestive and immunological function in neonates: role of early nutrition. Livest Prod Sci 2000, 66: 161-167.

[6] Keelan M, Walker K, Thomson ABR. Intestinal morphology, marker enzymes and lipid content of brush border membranes from rabbit jejunum and ileum: effect of aging. Mech Ageing Dev 1985, 31: 49-68.

[7] $\mathrm{Yu} \mathrm{B}$, Chiou PWS. The morphological changes of intestinal mucosa in growing rabbits. Lab Anim 1997, 31: 254-263.

[8] Van der Hage MH. The morphogenesis of the small intestinal mucosa of the rabbit. A stereomicroscopical study. In: Proc 4th World Rabbit Science Association, Budapest, 10-14 Oct 1988, 3: 347-355.

[9] Gutiérrez I, Espinosa A, García J, Carabaño R, De Blas JC. Effect of levels of starch, fiber, and lactose on digestion and growth performance of early-weaned rabbits. J Anim Sci 2002, 80: 1029-1037.
[10] Fortun-Lamothe L, Gidenne T, Lapanouse A, De Dapper J. Note: an original system to separately control litter and female feed intake without modification of the mother-young relations. World Rabbit Sci 2000, 8: 177-180.

[11] Van Soest PJ, Robertson JB, Lewis BA. Methods for dietary fiber, neutral detergent fiber, and non starch polysaccharides in relation to animal nutrition. J Dairy Sci 1991, 74: 3583 3597.

[12] Alstin F, Nilsson M. Le système d'hydrolyse Soxtec ${ }^{\circledR}$ améliore les méthodes officielles de dosage des matières grasses totales. Ind Aliment Agric 1990, 107: 1271-1274.

[13] Folch J, Lees M, Stanley GHS. A simple method for the isolation and purification of total lipides from animal tissues. J Biol Chem 1957, 226: 497-509.

[14] Goodlad RA, Levi S, Lee CY, Mandir N, Hodgson H, Wright NA. Morphometry and cell proliferation in endoscopic biopsies: Evaluation of a technique. Gastroenterology 1991, 101: 1235-1241.

[15] Statistical Analysis System. SAS User's guide, Version 8, SAS Institute Inc., Cary, NC, 1999.

[16] Scapinello C, Gidenne T, Fortun-Lamothe L. Digestive capacity of the rabbit during the post-weaning period, according to the milk/ solid feed intake pattern before weaning. Reprod Nutr Dev 1999, 39: 423-432.

[17] Xicatto G, Trocino A, Sartori A, Queaque PI. Effect of weaning diet and weaning age on growth, body composition and caecal fermentation of young rabbits. Anim Sci 2003, 77: $101-111$.

[18] Lebas F. Composition chimique du lait de lapine, évolution au cours de la traite et en fonction du stade de lactation. Ann Zootech 1971, 20: 185-191.

[19] El-Sayiad GHA, Habeeb AAM, El-Maghawry AM. A note on the effects of breed, stage of lactation and pregnancy status on milk composition of rabbits. Anim Prod 1994, 58: 153 157.

[20] Pascual JJ, Cervera C, Blas E, FernándezCarmona J. Effect of high fat diets on the performance, milk yield and milk composition of multiparous rabbit does. Anim Sci 1999, 68: $151-162$

[21] Pascual JJ, Cervera C, Fernández-Carmona J. Effect of solid feed intake before weaning on the performance of growing rabbits. In: Proceedings of the second meeting of workgroups 3 and 4, COST Action 848, 29-30 June 2001, Godollo, Hungary, p 48. 
[22] Di Meo C, Stanco G, Piccolo G, Taranto S, Pia Gazaneo M, Nizza A. Productive performance of rabbits according to pre-weaning solid feed and milk intake. Ital J Anim Sci 2003, 2: 51-58.

[23] Xiccato G, Trocino A, Sartori A, Queaque PI. Influence de l'âge, du sevrage précoce et de l'aliment sur le développement des organes digestifs et des fermentations cæcales chez le jeune lapin. 9es Journées de la Recherche Cunicole, Paris, 2001, p 199-202.

[24] Laplace JP, Lebas F. Mensurations viscérales chez le lapin. II.-Principaux facteurs déterminants des variations relatives de la croissance du foie, des reins et des segments intestinaux entre 3 et 11 semaines d'âge. Ann Zootech 1972, 21: 505-524.

[25] Pluske JR, Hampson DJ, Williams IH. Factors influencing the structure and function of the small intestine in the weaned pig: a review. Livest Prod Sci 1997, 51: 215-236.

[26] Marion J, Biernat M, Thomas F, Savary G, Le Breton Y, Zabielski R, Le Huërou-Luron I, Le Dividich J. Small intestine growth and morphometry in piglets weaned at 7 days of age. Effects of level of energy intake. Reprod Nutr Dev 2002, 42: 339-354.

[27] Albinsson ARM, Andersson GKA. Subclinical characteristics of the wasting pig syndrome. Res Vet Sci 1990, 49: 71-76.

[28] Odle J, Zijlstra RT, Donovan SM. Intestinal effects of milkborne growth factors in neonates of agricultural importance. J Anim Sci 1996, 74: 2509-2522.

[29] Grant AL, Thomas JW, King KJ, Liesman JS Effects of dietary amines on small intestinal variables in neonatal pigs fed soy protein isolate. J Anim Sci 1990, 68: 363-371.

[30] Marion J, Bébin K, Thomas F, Piot M, Fauquant J, Louveau I, Ganier P, Thibault JN, Maubois JL, Sève B, Le Huërou-Luron I, Le Dividich J. 2002. La supplémentation de l'aliment de sevrage en un extrait de colostrum bovin augmente la hauteur des villosités dans le duodénum chez le porcelet sevré. $34^{\mathrm{es}}$ Journées de la Recherche Porcine en France, Paris, 2002, p 103-108.

[31] Spreeuwenberg MAM, Verdonk JMAJ, Gaskins HR, Verstegen MWA. Small Intestine Epithelial Barrier Function Is Compromised in Pigs with Low Feed Intake at Weaning. J Nutr 2001, 131: 1520-1527.

[32] Wiese F, Simon O, Weyrauch D. Morphology of the Small Intestine of Weaned Piglets and a Novel Method for Morphometric Evaluation. Anat Histol Embryol 2003, 32: 102-109.

[33] Chiou PWS, Yu B, Lin C. Effect of different components of dietary fiber on the intestinal morphology of domestic rabbits. Comp Biochem Physiol A 1994, 108: 629-638.

[34] Dunsford BR, Knabe DA, Haensly WE. Effect of dietary soybean meal on the microscopic anatomy of the small intestine in the early-weaned pig. J Anim Sci 1989, 67: 18551863

[35] Pluske JR, Williams IH, Aherne FX. Maintenance of villous height and crypt depth in piglets by providing continuous nutrition after weaning. Anim Sci 1996, 62: 131-144.

[36] Pluske JR, Williams IH, Aherne FX. Villous height and crypt depth in piglets in response to increases in the intake of cows'milk after weaning. Anim Sci 1996, 62: 145-158.

[37] Van Beers-Schreurs HMG, Nabuurs MJA, Vellenga L, Kalbeek-van der Valk HJ, Wensing T, Breukink HJ. Weaning and the weanling diet influence the villous height and crypt depth in the small intestine of pigs and alter the concentrations of short-chain fatty acids in the large intestine and blood. J Nutr 1998, 128 : 947-953.

[38] Takeuchi T, Gonda T. Cellular kinetics of villous epithelial cells and $\mathrm{M}$ cells in rabbit small intestine. J Vet Med Sci 2004, 66: 689-693.

[39] Toofanian F, Targowski SP. Morphogenesis of rabbit small intestinal mucosa. Am J Vet Res 1982, 43: 2213-2219. 